\title{
A Brief Discussion on Strategies to Control Safety Risks of Investment and Exploitation of Overseas Mineral Resources
}

\author{
Lin Zhifeng \\ Faculty of Land Resource Engineering, Kunming \\ University of Science and Technology, 650093, \\ Kunming, China \\ 75482412@qq.com
}

\begin{abstract}
Based on the analysis of multiple factors that had influenced the safety of investment and exploitation of overseas mineral resources, such as political, legal, macroeconomic, resources, market, community, public relation and other risks, this article built a safety evaluation system of investment and exploitation of overseas mineral resources. Furthermore, it combined with the current condition of safety problems in investment and exploitation of mineral resources with some experiences and practices that are executed in developed countries to guarantee safety of mineral resources, and then proposed several strategies to control risks of safety of investment and exploitation of overseas mineral resources, for example, to develop active "resources-oriented diplomacy", raise awareness to affect overseas insurance, improve financial support system merged overseas, attach importance to safety management and environmental protection, accelerate cultivation of international managing talents and enhance contacts and communication with local government and masses, which will provide reference for mineral resources companies to strengthen prevention and control on safety risks during the processes to implement international strategies.
\end{abstract}

Keywords-Overseas; Mineral Resources; International; Safety Risks; Risk Evaluation; Control Strategies

\section{INTRODUCTION}

With the development of economic globalization, in order to solve the conflict of shortage of domestic resources that exists for a long time, seek for new approaches to obtain mineral resources and ensure to meet the needs of their own rapid development, many companies around the world begin to extend their sights overseas, go abroad, propose and implement international management strategies and attempt to participate in international competition of mineral resources in the world. However, the mineral resources industry is a tough one with great risk, which needs the investing and exploiting companies to pay huge efforts to achieve success. Through the analysis on data disclosed by relevant domestic and foreign authorities, currently, it is found that there is great risk in managing investment and exploitation of overseas mineral resources. According to relevant theories from domestic and foreign researches on mineral resources safety, combining with actual conditions and existing problems on safety of overseas mineral resources with the experiences and practices that economically advanced countries have employed to guarantee mineral resources safety, this article focuses on studying and discussing on the main risks that may appear during investment and exploitation of overseas mineral resources and how to prevent these risks.

\section{MAIN RISKS}

The risks of investment and exploitation of overseas mineral resources refer to the possibilities of failure, major losses or even disaster happening to cooperative strategies of overseas resources, which is resulted from a series of unnatural and uncertain factors [1]. Based on classification of risk by world experts and scholars, in accordance with origins of transnational investment risks that overseas mineral resources companies may suffer, the investment and exploitation risks for these companies can be divided into external and internal risks. The external risk primarily includes political, legal, macro-economic, resources, market, community and public relation risks; and the internal risk mainly includes such risks in business decision, investment and financing and project implementation and management.

\section{A. Political Risk}

Political risk refers to a kind of loss brought to foreign investors due to sudden change in domestic political, legal or social environ ment of host country or political relation between host and other countries. It mainly includes expropriation, exchange restriction, war and civil strife and governmental default risks. Besides, it also includes delayed payment risk due to suspension or delay of payment by host government, under which condition the foreign investors are unable to duly and fully receive principal and interest of mature bonds as well as profit of investment [2].

\section{B. Legal Risk}

Legal risk refers to some potential or occurred major economic losses brought to companies from economic disputes and lawsuits which are resulted from that the companies do not understand legal rules of host countries, neglect legal review or evade legal regulation in business operation; or the possibilities of negative legal consequences to companies due to changes of legal environment outside the companies or that the subject including the companies themselves fail to effectively exercise rights and obligations under laws and contract. 


\section{Macro-economic Risk}

Macro-economic risk is resulted from economic changes during overseas resources investment and exploitation by companies. A lot of contents may affect macro-economic risk, which mainly include stability of economic development in host country, influence of international economic environ ment, exchange change in international financial market, etc. [3]

\section{Resources Risk}

Resources risk is due to deviation made by metallogenic belt minerals, ore grade, reserves and mining degree in mining investment [4]. By reason of the risks due from above factors, there will be a large derivation between actual situation and originally predicted results, and consequently the project will get an increased mining cost, reduced output or shortened production life.

\section{E. Market Risk}

Market risk refers to that the uncertain market conditions of locating country of resources lead to an uncertain mining investment. Market risk mainly includes prices of minerals, uncertain supply, competition degree with other mining companies, condition of alternative minerals, etc. Moreover, market risk also includes effect of economic cycle and restrictions by development degree of mineral resources market. Mining industry is the foundation of national economy with activity cycle of 4 stages-boom, recession, depression and recovery. Its development is directly affected by status of national economy and its cyclical swing will also directly impact on sales volume and price of product in mining companies [5] In addition, due to imperfect development of overseas minerals market, there is still serious local protectionis $\mathrm{m}$ in some countries and they often set certain policy barriers to prevent potential foreign investors, which restrain a normal development of minerals market to a large extent and bring huge market risk to mineral resources companies.

\section{F. Community and Public Relation risk}

During overseas minerals exploitation, the mineral resources companies are largely affected by local community. Once failing to handle with it well, it certainly will affect the companies to effectively operate. Community and public relation risks mainly include effect of community security and cultural difference on project, labor union and troubles problem, etc. [6]

\section{G. Business Decision Risk}

That whether a company has scientific decisionmaking mechanism and process may globally affect overseas resources development strategy. Under influence of traditional culture and business management system, over so many years, the decision-making subjects of some companies have mainly been their heads and a great number of project decisions are significantly affected by achievements. These people always chase for record of achievements rather than focusing on overall project benefits, therefore, it is difficult to ensure a scientific decision so that to increase project risk greatly[7].

\section{H. Investment and Financing Risks}

Investment and financing collectively refer to decisionmaking of investment and financing (who invests),

collection of investment (source of funds) and investment usage (how to invest) in the process of resources allocation. They are specific manifestation of investment and financing activities. Thus, if overseas companies take improper modes of decision-making of investment and financing, collection of investment and investment usage or fail to handle properly in process of specific implementation, they may face to great losses.

\section{Project Management Risk}

Generally, overseas projects of mineral resources companies are featured by large time span and complex levels. In project organization and implementation, there are many procedures and related links, such as feasibility research, project approval, designing, organizing of construction, completion and acceptance, pilot production(commissioning), etc., which may guarantee the projects to be successfully implemented. However, any failure of procedure or link will lead to final defeat of project investment.

\section{RISK ASSESSMENTS}

\section{A. Risk Evaluation Indicator System}

Through previous analysis on main risks of investment and exploitation of overseas mineral resources, by reference of opinions of relevant experts, under scientific selection, the risk evaluation indicators of investment and exploitation of overseas mineral resources are divided into 2 categories-external and internal risks, and further divided into 9 risks; then these 9 risks are subdivided into 23 indicators. Finally, a risk evaluation indicator system of investment and exploitation of overseas mineral resources is built.

\section{B. Risk Evaluation Method and Processes}

The risk evaluation system of overseas minerals resources investment uses the analytic hierarchy process. Then, through querying for data and consulting relevant experts, it analyzes and compares the hierarchical structure of evaluation system to further build judgment matrix and finally work out weight of each evaluation indicators. For a four-leveled indicator hierarchical structure, a pair-wise comparis on from level to level shall be used to ascertain relative importance among indicators. In this article, 12 judgment matrix are built up, and then matrix calculation and consistency testing shall be conducted respectively (in which the second-order matrix made of two indicators is always consistent so that it is unnecess ary to test) to finally obtain each indicator weight and single and overall hierarchical arrangements, as shown in Table 1-12.

TABLE 1 POLITICAL RISK INDICATOR WEIGHT

\begin{tabular}{|c|c|c|c|c|}
\hline & D1 & D2 & D3 & Weight \\
\hline D1 & 1 & $1 / 3$ & 3 & 0.2426 \\
\hline$\overline{\mathrm{D} 2}$ & 3 & 1 & 7 & 0.6694 \\
\hline D3 & $1 / 3$ & $1 / 7$ & 1 & 0.0879 \\
\hline
\end{tabular}


TABLE 2 LEGAL RISK INDICATOR WEIGHT

\begin{tabular}{|c|c|c|c|}
\hline & D4 & D5 & Weight \\
\hline D4 & 1 & 3 & 0.75 \\
\hline D5 & $1 / 3$ & 1 & 0.25 \\
\hline
\end{tabular}

TABLE 3 MACRO-ECONOMIC RISK INDICATOR WEIGHT

\begin{tabular}{|c|c|c|c|}
\hline & D6 & D7 & Weight \\
\hline D6 & 1 & $1 / 4$ & 0.2 \\
\hline D7 & 4 & 1 & 0.8 \\
\hline
\end{tabular}

TABLE 4 RESOURCES RISK INDICATOR WEIGHT

\begin{tabular}{|c|c|c|c|c|}
\hline & D8 & D9 & D10 & Weight \\
\hline D8 & 1 & $1 / 3$ & 3 & 0.2582 \\
\hline D9 & 3 & 1 & 5 & 0.6369 \\
\hline D10 & $1 / 3$ & $1 / 5$ & 1 & 0.1047 \\
\hline
\end{tabular}

In which, $\mathrm{CR}=0.03703<0.1$, in accordance with consistency testing.

TABLE 5 MARKET RISK INDICATOR WEIGHT

\begin{tabular}{|c|c|c|c|c|}
\hline & $\mathrm{D} 11$ & $\mathrm{D} 12$ & $\mathrm{D} 13$ & Weight \\
\hline $\mathrm{D} 11$ & 1 & $1 / 3$ & 5 & 0.6483 \\
\hline $\mathrm{D} 12$ & $1 / 3$ & 1 & 2 & 0.2296 \\
\hline $\mathrm{D} 13$ & $1 / 5$ & $1 / 2$ & 1 & 0.1221 \\
\hline \multicolumn{4}{|r}{ In which, CR $=0.003552<0.1$ in accordance with }
\end{tabular}

consistency testing.

TABLE 6 COMMUNITY \& PUBLIC RELATION RISK INDICATOR WEIGHT

\begin{tabular}{|c|c|c|c|c|}
\hline & D14 & D15 & D16 & Weight \\
\hline D14 & 1 & 3 & 2 & 0.5396 \\
\hline D15 & $1 / 3$ & 1 & $1 / 2$ & 0.1634 \\
\hline D16 & $1 / 2$ & 2 & 1 & 0.2969 \\
\hline
\end{tabular}

In which, $\mathrm{CR}=0.008849<0.1$, in accordance with

consistency testing.

TABLE 7 BUSINESS DECISIONS RISK INDICATOR WEIGHT

\begin{tabular}{|c|c|c|c|}
\hline & D17 & D18 & Weight \\
\hline D17 & 1 & 5 & 0.83 \\
\hline D18 & $1 / 5$ & 1 & 0.17 \\
\hline
\end{tabular}

TABLE 8 INVESTMENT AND FINANCING RISK INDICATOR WEIGHT

\begin{tabular}{|c|c|c|c|}
\hline & D19 & D20 & Weight \\
\hline D19 & 1 & 6 & 0.86 \\
\hline D20 & $1 / 6$ & 1 & 0.14 \\
\hline
\end{tabular}

TABLE 9 PROJECT IMPLEMENTATION AND MANAGEMENT RISK INDICATOR WEIGHT

\begin{tabular}{|c|c|c|c|c|}
\hline & D21 & D22 & D23 & Weight \\
\hline D21 & 1 & $1 / 3$ & $1 / 5$ & 0.1095 \\
\hline D22 & 3 & 1 & $1 / 2$ & 0.3089 \\
\hline D23 & 5 & 2 & 1 & 0.5816 \\
\hline
\end{tabular}

In which, $\mathrm{CR}=0.003552498<0.1$, in accordance with consistency testing.
TABLE 10 EXTERNAL RISK INDICATOR WEIGHT

\begin{tabular}{|c|c|c|c|c|c|c|c|}
\hline & D1 & D2 & D3 & D4 & D5 & D6 & Weight \\
\hline D1 & 1 & 3 & 2 & 5 & 7 & 9 & 0.4232 \\
\hline D2 & $1 / 3$ & 1 & $1 / 2$ & 2 & 3 & 4 & 0.1516 \\
\hline D3 & $1 / 2$ & 2 & 1 & 3 & 4 & 5 & 0.2381 \\
\hline D4 & $1 / 5$ & $1 / 2$ & $1 / 3$ & 1 & 2 & 3 & 0.0920 \\
\hline D5 & $1 / 7$ & $1 / 3$ & $1 / 4$ & $1 / 2$ & 1 & 2 & 0.0575 \\
\hline D6 & $1 / 9$ & $1 / 4$ & $1 / 5$ & $1 / 3$ & $1 / 2$ & 1 & 0.0376 \\
\hline
\end{tabular}

In which, $\mathrm{CR}=0.011698468<0.1$, in accordance with consistency testing.

TABLE 11 INTERNAL RISK INDICATOR WEIGHT

\begin{tabular}{|c|c|c|c|c|}
\hline & D21 & D22 & D23 & Weight \\
\hline D21 & 1 & 4 & 7 & 0.7153 \\
\hline D22 & $1 / 4$ & 1 & 2 & 0.1869 \\
\hline D23 & $1 / 7$ & $1 / 2$ & 1 & 0.0977 \\
\hline
\end{tabular}

In which, $\mathrm{CR}=0.001905297<0.1$, in accordance with consistency testing.

TABLE 12 RISK INDICATOR WEIGHT OF MAIN CRITERION LEVEL

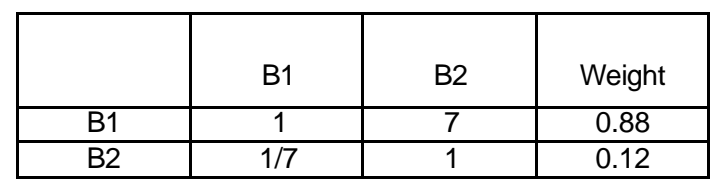

Based upon the above evaluation processes, it is found that external risk occupies a large proportion of risks of investment and exploitation of overseas mineral resources. Among external risks, political risk wins the first place, followed by macro-economic and legal risks. In 23 indicators, the most important one shall be political stability of invested host country. Therefore, before investing overseas mineral resources, it is essential for a company to evaluate political risk in advance, and then respectively carry on risk prevention according to importance relationship among each indicator [8].

\section{SPECIFIC MEASURES}

Through assessment on risk evaluation system of investment and exploitation safety of overseas mineral resources, combining actual conditions on investment and exploitation safety of overseas mineral resources with the experiences and practices that developed countries have employed to guarantee mineral resources safety, and some specific measures have been proposed as follows:

1) Actively develop "Resource-oriented diplomacy" and enhance communication and negotiation on mineral resources problems. The resources importing countries shall set up all-around and close bilateral relation with resources exporting countries and potential exporting countries, and list the communications with these countries in important agenda of national foreign affairs; through mutual communications and understanding between countries, they shall establish strategic or economic cooperative partner relationship as possible in order to lay good political foundation for overseas companies to invest and exploit mineral resources.

2) The companies shall raise awareness of covering overseas insurance. Political risk can significantly affect overseas investing company than other risks. Once it happens, the companies will suffer immeasurable losses. So when the companies make investment and exploitation in resources countries with large political risk, they shall be aware of covering overseas insurance. For example, the 
People's Insurance Corporation of China (PICC), the Export-Import Bank of China (EIBC) and China Export \& Credit Insurance Corporation (CECIC) have already set insuring business on political risks of overseas investment [9]. The Chinese companies could cover insurance in these financial agents to avoid political risk during exploitation of overseas mineral resources.

3) Strengthen and improve the financial support system of overseas merger, and help the company to reduce investment and financing risks to a maximum degree. An overseas mineral resources merger generally involves a large amount of fund. Sometimes, it is hard for the merging party to independently assume large-scaled payment of cash. Therefore, the resources importing countries should establish and improve its financial support system of overseas merger, encourage domestic banks to customize particular and professional financial products according to features of company's overseas merger; moreover, they should strongly develop domestic financial market and create diversified financing channels and tools in order to reduce financing costs of company and spread risks of investment and financing [10].

4) Broaden democratic channel and set scientific democratic decision-making mechanism of investment and exploitation of resource project. A company shall firstly establish scientific and democratic decision-making process. During the period of discussion on investing foreign project, the company shall fully listen to feasibility research report proposed by project team; think highly of and take the opinions that the experts of technical, financial, risk and legal team have made after reviewing this project; and finally make decisions collectively by the decision-makers of the company. It is forbidden to make hasty decision or make one person alone to have final say.

5) Highlight the safety management and environmental protection. In implementation of operation and management of overseas mineral resources project, a company must highlight safety work and establish and improve safety management system and incentive measures of mine project construction and production, which should be closely related with performance assessment and employment of managerial staff. Furthermore, the company shall highlight environmental protection of project construction location; pay attention to communication, negotiation and contacts with local government and masses; take feasible measures to protect ambient environment around the mining areas; and set safety, civilization, first-class environment and harmonious community as its primary target in foreign project construction.

6) Conduct due diligence, feasible research and organization work before project investment. Before bringing merger and acquisition of resources project into reality, it is necessary to entrust specialized agent to make thorough investigation on political, economic, laws and regulations, tax, environmental assessment and other data of the country where the intended merger project will be located, and then obtain authoritative information and data of above-mentioned aspects; on the other hand, they should build scientific project feasible research and analytical processes, and organize relevant experts and technical staff to carefully analyze, study on and review various data obtained from due diligence by project team.
After the investment project is discussed and approved by decision-makers of company, it is also important to arrange design, construction, supervision, final acceptance and commissioning of the project carefully and seriously.

7) Accelerate the cultivation of international managing talents. A talent acquisition and cultivation plan shall be worked out and set its criterion to include thorough understanding of international investment, finance, trade and necessary professional knowledge, being familiar with international conventions, environment and market and knowing history, cultural background, political environment, laws and regulations, economic status, etc. Thus the company may get support and supply of human resource during overseas investment.

8) Enhance contacts and communications with local government and masses. An overseas investing company shall "do in Rome as the Romans do", know folk culture of host country in detail and provide systematic training for staffs on custom, religious belief, value idea, cultural background and basic legal system of host country. Besides, the company shall depend on needs of production, operation and development to employ more local staff as possible so as to effectively reduce cultural diversity risk and transnational operation costs, make close relationship with local government and masses of host country and thus lessen policy restriction and antipathy of host country on foreign investment input.

\section{CONCLUSIONS}

In a word, internationalization of mineral resources is a road that an overseas company must follow, in order to participate in the international competition. However, it is a vital thing to enhance the risk control of investment and exploitation safety of overseas mineral resources. Therefore, both resource importing country and overseas company shall learn from good experience of other countries and companies on their risk prevention and control of investment and exploitation safety of mineral resources with an open mind, and absorb and continually innovate on basis of practices of these investment and exploitation, so that the overseas mineral resources company can do a good job of risk prevention and control of investment and exploitation and practically guarantee its internationalized operational strategic target to be smoothly implemented.

\section{REFERENCES}

[1] Qin Yuan-jian, He La-bo. The causes and constitution of strategic risks of overseas resources cooperation of Chinese companies [J]. Development and Research, 2009 (4) :116-119.

[2] Zhang Shi-chao. A research on strategies and risk control of Chinese overseas expanding non-energy mining company [D]. Changsha: Zhongnan University, 2009.

[3] Qi Ye. A research on risk assessment of overseas exploitation project of Chinese oil company [D]. Harbin: Harbin University of Science and Technology, 2014.

[4] Liu Feng. A research on risk assessment of foreign mineral resources exploitation and selection [D]. Changsha: Zhongnan University, 2009.

[5] Li Kui-xing. A brief discussion on risk management of mining investment [J]. China Mining, 2009,18, (12) :35-37.

[6] Ren Jie. A research on risk assessment and real option of investing overseas mineral resources project [D]. Beijing: China University of Geosciences (Beijing),2014. 
[7] Xie Lin-lin. A research on decision-making mechanism of public investment and construction project [D]. Chongqing: Chongqing University, 2005.

[8] Tian Ze. A research on risk assessment of overseas investment of Chinese companies [J]. Inquiring into Modern Economy, 2013 (11) : 46-50.
[9] Cheng Jin-hua, Sheng Tong. An analysis on political risks in transnational operation of Chinese oil company [J]. China Soft Science, 2006 (4) : 24-32.

[10] Shi Yu-you. The risk assessment and control of overseas mineral resources merger of Chinese companies [J]. China Circulation Economy, 2012(9):61-66. 